\title{
Connecting Social Capital, Cognitive Bias, and Entrepreneurial Intentions: About Gender Differences
}

\author{
Lin-Ju Cheng \\ Department of Marketing and Logistics Management, St. John's University \\ E-Mail: clrvicky@mail.sju.edu.tw \\ Chun-Chieh Liao * \\ Department of International Trade, Chinese Culture University \\ E-Mail : twtwliao@gmail.com
}

\begin{abstract}
This study combines the SC-E model and entrepreneurial bias research to formulate a "social capital-cognitive bias-entrepreneurial intentions framework," and to discuss the differences between gender in the relationship among social capital, cognitive bias, and entrepreneurial intentions. Additionally, it also explores the mediation effects of optimism and overconfidence. Structural equation modeling is used to examine the hypotheses on a sample of 511 students at a Taiwanese university. Empirical results show that neither bonding nor bridging social capital has a direct impact on entrepreneurial intentions. They also indicate that male students are more optimistic and have higher entrepreneurial intentions than females. Regarding the mediation effect, bridging social capital may evoke both optimism and overconfidence, but bonding social capital only affects optimism. Furthermore, optimism is the antecedent of overconfidence, and it creates another channel of the mediation effect.
\end{abstract}

Keywords: Entrepreneuriship, Social capital, Optimism, Overconfidence, Entrepreneurial intentions.

\section{INTRODUCTION}

With the rise of network technologies, soft power has become the key to future competition in the international market. Industrial development is currently faced with unprecedented challenges: Development has shifted from being technology-intensive to being innovation-intensive. In particular, the gradual popularization of information 
technologies has dramatically reduced the operating and marketing costs of new ventures, giving aspiring, promising young people the opportunities and capabilities to compete in the global market through entrepreneurship. Praag and Versloot (2007) indicated that based on the changeable labor market, governments and policymakers should search for new ways to drive innovation and create jobs. The entrepreneurial boom is unprecedented presently, which brings opportunities for young people. According to the Global Entrepreneurship Monitor (GEM) 2018 global report, sixty-six percent of adults see entrepreneurship as the right career choice, and about three-fourths of adults in the Netherlands, Poland, and Sweden have the same perspective. This tendency has influenced young people worldwide, and entrepreneurship has become an attractive career choice among youngsters from all around the world (Lewis, Harris, Morrison, \& Ho, 2015; Singer, Amorós, \& Arreola, 2015).

However, starting a business venture involves a complex and challenging decisionmaking process (Pérez-López, González-López, \& Rodríguez-Ariza, 2016) in which essential factors must be considered, such as the choice of business partners, a source of funds, and the choice of industry. Before the actual foundation of a business venture, entrepreneurial intentions are the core factors and the best signals for entrepreneurial action (Kruger, 1993; Minhas, 2018). Kautonen, Gelderen, and Fink (2015) also confirmed that entrepreneurial intentions predict entrepreneurial action. On the other hand, prior studies have discussed which factors influence entrepreneurial intentions (Kautonen et al., 2015; Schlaegel \& Koenig, 2014): Some suggest external factors, such as social capital (Liñán \& Santos, 2007) or education background (Karimi, Biemans, Lans, Chizari, \& Mulder, 2016; Gurel et al., 2010); whereas others assert its internal psychology personality (Asante \& Affum-Osei, 2019). Previous studies have less explored external and internal factors simultaneously. Thus, this paper adopts a comprehensive perspective, including external (e.g., social capital) and internal factors (e.g., optimism \& overconfidence), to formulate the integrated model and discuss the relationship between antecedent factors and entrepreneurial intentions.

Entrepreneurial bias research (Bird, 1988; Mitchell, Busenitz, Lant, McDougall, Morse, \& Smith, 2002) indicates that entrepreneurs differ from other people in terms of internal personality traits and cognitive psychological processes (Fayolle \& Liñán, 2014), such as the perception of risk, optimism, and overconfidence (Koellinger, Minniti, \& Schade, 2007; Hayward, Forster, Sarasvathy, \& Fredrickson, 2010), and investigates how entrepreneurs perceive and think about entrepreneurship. Previous studies find that entrepreneurs with cognitive bias have managed to create new ventures (Seligman \& Schulman, 1986; Buttar, 2015). Thus, these results provide a different perspective that suggests cognitive bias allows for quick and straightforward decisionmaking and more accurate judgments (Goldstein \& Gigerenzer, 2002, 2009). The 
application of the cognitive bias, of which the researcher distinguishes many types, has been studied in entrepreneurship research (Herz, Schunk, \& Zehnder, 2014; Bernoster, Rietveld, Thurik, \& Torrès, 2018). However, despite the two cognitive biases possessed by some entrepreneurs, optimism and overconfidence, usually being discussed together, they represent two distinct constructs that influence entrepreneurship in different ways (Lowe \& Ziedonis, 2006). Optimism refers to a tendency underestimate the difficulty of tasks, and is a common and stable personality trait (Trevelyan, 2008) not limited to specific situations (Griffin \& Varey, 1996; Trevelyan, 2008); overconfidence refers to a tendency to overestimate the probability of positive events occurring (Moore \& Healy, 2008) and is limited to specific situations (Griffin \& Varey, 1996). Optimism is a longterm and stable personality trait that is difficult to change, while overconfidence is a reaction to specific events. However, prior studies used optimism and overconfidence interchangeably (Cassar, 2010) and conflated (Trevelyan, 2008; Giacomin, Janssen, \& Shinnar, 2016), and fail to discuss their differences. Parker (2009) indicated that conflating optimism and overconfidence should not be encouraged in the future. Besides, few studies discuss the relationship between optimism, overconfidence, and entrepreneurial behavior (Herz et al., 2014; Bernoster et al., 2018). To sum up, it is necessary to distinguish between two kinds of internal psychological factors, optimism and overconfidence, and clarify their effects on entrepreneurial intentions, which is the purpose of this study.

Concerning the question of how social capital influences entrepreneurial intentions, the social capital entrepreneurship (SC-E) model, which considers how an entrepreneur's resources influence business ventures, is proposed by Murphy (2011). The model considers that the essential elements of entrepreneurship are social capital and the connections of the entrepreneur since these factors help a new business venture gain resources (Brüderl \& Preisendorfer, 1998) and provide the entrepreneur with psychological support (Shepherd \& Krueger, 2002) and encouragement, which in turn, affects their entrepreneurial intentions significantly (Liao \& Welsch, 2005). Therefore, social capital is a multidimensional variable (Nahapiet \& Ghoshal, 1998), being categorized variously in different studies. In such, this study adopts a series of studies proposed by Putnam (2000), distinguishing two types of social capital, bonding and bridging, which complement each other. Bonding social capital groups together similar individuals, emphasizing strong relationships between family members and close friends that provide a sense of security, psychological and emotional support, and tangible assistance (Coleman, 1988). Such strong ties use trust as an essential mechanism (Granovetter, 1985; Nahapiet \& Ghoshal, 1998). Bridging social capital groups together individuals from different communities, among whom interpersonal relationships are not close, but the exchange and sharing of information and interaction 
are enabled (Granovetter, 1973). Such weak ties allow individuals to expand their vision and widen their knowledge (Williams, 2006). This paper analyzes the differences between these two types of external social capital and investigates their direct and indirect impact on entrepreneurial intentions.

As mentioned above, this study considers that the SC-E model focuses on entrepreneurs' resources, and applies a social perspective, emphasizing the external social resources that entrepreneurs have. Whereas, entrepreneurial bias research focuses on their thought processes and applies a psychological perspective, meaning that which constitutes an internal entrepreneurial mindset. Meanwhile, Butter's (2015) evidence found that social capital possessed by an entrepreneur is also an essential prerequisite for cognitive bias. However, past studies have explored the influence that social resources and having an internal entrepreneurial mindset have on entrepreneurial intentions, respectively, to discuss their cause-effect relationships without the integration of external/internal factors and entrepreneurial intentions. Therefore, this study represents a more comprehensive perspective, combining external and internal factors simultaneously to formulate the "social capital-cognitive bias-entrepreneurial intentions framework." Social capital is categorized as bonding and bridging, emphasizing the entrepreneurs' external social resources; thus, the cognitive biases of optimism and overconfidence are separated, rather than discussed as a single item, while focusing on the entrepreneurs' internal mindset. Besides, this study also discusses the mediating role of optimism and overconfidence in social capital's effect, as well as the latter's direct influence on entrepreneurial intentions.

Another purpose of this study is to examine gender differences in entrepreneurial intentions and their determinants. Empirical evidence suggests that men express stronger entrepreneurial intentions than women (Díaz-García \& Jiménez-Moreno, 2010; Nowiński, Haddoud, Lančarič, Egerová, \& Czeglédi, 2019; Shinnar, Hsu, Powell, \& Zhou, 2018; Tognazzo, Gubitta, \& Gianecchini, 2016; Zampetakis, Bakatsaki, Litos, Kafetsios, \& Moustakis, 2017). Drawing on the theory of planned behavior, DíazGarcía et al. (2010) proposed that gender plays a key role in entrepreneurship factors and entrepreneurial intentions. However, few previous researches have discussed the gender differences of social capital and cognitive bias constructs in shaping entrepreneurial intentions. To fill the gap, this study adopts the "social capital-cognitive bias-entrepreneurial intentions framework" and focuses on the role of gender towards entrepreneurship within the proposed model. First, the model is tested separately for each male and female subsample to test its robustness, as well as the mediation effects of optimism and overconfidence. Then, it compares the five entrepreneurship-related constructs between male and female students. Questionnaires were distributed to students taking at least one of the five entrepreneurship courses at the Taiwanese 
university; the empirical results and managerial implications will be discussed in this study.

\section{THEORETICAL BACKGROUND AND HYPOTHESES}

\section{Social Capital, Entrepreneurial Intentions and Gender}

The gender issue in entrepreneurial intentions has been addressed in the literature (Gorji \& Rahimian, 2011; Espíritu-Olmos, \& Sastre-Castillo, 2015). Gupta, Turban, Wasti, \& Sikdar (2009) indicated that male entrepreneurs are considered to be associated with characteristics such as independence, dominance, aggressiveness, challenge, and risk-taking. In a similar vein, women are said to have fewer financial and human network resources (Becker-Blease \& Sohl, 2007), as well as less management experience (Brush, Carter, Gatewood, Greene, \& Hart, 2004). As such, despite the recent dramatic increase in female entrepreneurs in most countries, the level of women's choices to pursue a career in entrepreneurship is still lower than that of men (Mueller \& Dato-on, 2013). In such, other variables exist between gender and entrepreneurial intentions, and it is necessary to find out and discuss these relationships.

The gender differences in social networks stem from disparities in which men and women are linked to others in their social ties (Seibert, Kraimer, \& Liden, 2001). Granovetter (1973) divided social ties into two groups: Strong ties and weak ties. Kim (2017) indicated that weak ties bear a resemblance to bridging social capital, whereas strong ties correspond to bonding social capital. Weak ties (acquaintances, neighbors, coworkers) are not restricted to one narrow type of relationship, and they are more likely to reach outside of one's social clique to make a bridge from possibly disconnected groups or individuals (Kim \& Sherraden, 2014). Information and resources transmitted via weak networks tend to be unique and novel (Molyneux, 2002). Weak ties are useful in channeling information-related benefits (Burt 2005). Bridging social capital is like weak ties, and is comprised of individuals in the broader world from heterogeneous social backgrounds, providing different information and resources from those proffered by their immediate social circle (Williams, 2006).

In contrast, strong ties (family members \& friends) are frequent, emotionally close, and represent relationships that involve reciprocity. Strong ties exist between people who already have similar information and resources (Kim \& Sherraden, 2014). Thus, information obtained through strong ties tends to be confirmatory and redundant (Munch, McPherson, \& Smith-Lovin, 1997). Bonding social capital is similar to strong ties, and it brings together people with essential similarities, such as age, gender, and social class, emphasizing the strong interpersonal ties (Coleman, 1988). Bonding social capital provides a sense of security, as well as psychological and emotional support, or offers substantial assistance (Nahapiet \& Ghoshal, 1998), thus building trust and norms 
within groups. Previous literature provides evidence that men and women differ in composition and career advancement (Davies-Netzley, 1998). Moore (1990) found that women generally have networks made up of deep family and kin relationships, while men's networks consist of more professional acquaintances and consultants affiliated with formal associations (Robinson \& Stubberud, 2011).

Previous studies point out social capital is a critical factor for entrepreneurial opportunities (Shane \& Venkataraman, 2000; Baron \& Tang, 2009), as it has an impact on entrepreneurial careers (Liao \& Welsch, 2005) and newly created ventures (Baron \& Tang, 2009), social capital imbues entrepreneurs with a sense of security that in turn heightens their entrepreneurial intentions. Prior studies have pointed out that there are two common primary types of social capital, including bonding and bridging (Putnam, 2000; Adler \& Kwon, 2002).

In terms of bonding social capital, a favorable and robust network of family members and close friends provide useful social resources that help individuals develop new ventures, as well as offer a sense of security and support (Shane \& Venkataraman, 2000). Its value lies primarily in mutual trust, which generates collective consensus and good intentions that enhance innovative discoveries and entrepreneurial ideas (Coleman, 1988).

In conclusion, for new graduates intending to become entrepreneurs, their lack of personal relationships and resources required for starting businesses means that they must seek assistance from close friends and other members of their bonding social capital. Greater familiarity and trust make it easier to obtain the resources necessary for entrepreneurship and solve related issues, thereby fostering the development of new business ventures (Pérez-Macías, Fernández-Fernández, \& Rua Vieites, 2019). Therefore, this study proposes that:

$\mathbf{H}_{1}$ : Bonding social capital has a positive effect on entrepreneurial intentions; additionally, the path coefficient of males is higher than that of females.

In terms of bridging social capital, there are two direct benefits: Information and influence. Read, Song, and Smit (2009) pointed out that business partners are usually just friends. First, entrepreneurs may overcome their lack of business resources by becoming members of specific organizations or clubs (Bauernschuster, Falck, \& Heblich, 2010), and thus accelerate their acquisition of quality information at the right time (Burt, 1992; Adler \& Kwon, 2002). Second, entrepreneurs can accumulate favors through their social networks for future use, which explains the relationship between entrepreneurs' success and their social capital (Adler \& Kwon, 2002). Burt (1992) believed that bridging social capital is related to the creation of new ventures, in which 
competitive advantage lies in "the imperfect competition rendered by the social structure, which creates entrepreneurial opportunities for certain players" (p. 57).

As mentioned above, new graduates have relatively one-dimensional personal networks, but entrepreneurs who are willing to broaden their minds may make friends with people from different backgrounds and fields and expand their bridging social capital. The various ties reaching across networks directly increase the informational and influential power of bridging social capital, allowing entrepreneurs to access timely and high-quality information and to detect new business opportunities before other people, thereby increasing the chances of a business venture's success. Thus, this study proposes that:

$\mathbf{H}_{2}$ : Bridging social capital has a positive effect on entrepreneurial intentions; additionally, the path coefficient of males is higher than that of females.

\section{Optimism, Overconfidence, Entrepreneurial Intentions and Gender}

According to gender schema theory (Bem, 1981), people select, organize and interpret information to display gender-congruent behavior, which leads to highly differentiated judgments, including career choice (Martin, Ruble, \& Szkrybalo, 2002), traits, or socio-demographic variables (Masters \& Meier, 1988) and cognitive elements (Arenius \& Minniti, 2005).

Prior studies also have documented a gender difference in overconfidence, as support for men being more overconfident in a competitive environment (Niederle \& Vesterlund, 2007) and financial markets (Barber \& Odean, 2001). In the entrepreneurial field, Wilson, Kickul, and Marlino (2007) suggested that women reported lower confidence in their ability to run a business than men. Furthermore, men also appear to be more optimistic than women in a variety of settings, for example, in asset allocation (Jacobsen, Lee, Marquering, \& Zhang, 2014) and online purchases (Garbarino \& Strahilevitz, 2004). These gender differences in optimism may explain why men are willing to bear more risk compared to women, including starting a new business.

Social capital can shape an entrepreneur's cognitive characteristics, thereby affecting individuals starting new ventures. Mitchell et al. (2002) argued that entrepreneurs possess different psychological traits compared to other people, such as optimism and overconfidence (Trevelyan, 2008; Hayward et al., 2010). These two cognitive biases are well documented in the entrepreneurship literature (Shepherd, 2015). Cassar (2010) pointed out that optimism and overconfidence are used interchangeably, while Gudmundsson and Lechner (2013) and Giacomin et al. (2016) provided pieces of evidence for both constructs. Optimism refers to a tendency toward expecting positive outcomes, even without any rational justification (Hmieleski \& 
Baron, 2009), and is a stable long-term personality trait (Trevelyan, 2008) that could affect emotions and behaviors (Lounsbury, Steel, Loveland, \& Gibson, 2004). Overconfidence refers to an individual's overestimation of actual performance (Moore \& Healy, 2008) under exceptional circumstances in response to a particular situation (Griffin \& Varey, 1996). As such, this study considers optimism and overconfidence to be distinct constructs that are common among entrepreneurs and should be discussed separately.

Prior studies also find that optimism breeds higher self-esteem in entrepreneurs, who are less susceptible to feeling hurt, experience fewer emotional setbacks (Weinstein, 1982), and do not make additional preparations to lower risks (Weinstein, 1987). Optimism will positively affect entrepreneurs' overconfidence (Schaefer, Williams, Goodie, \& Campbell, 2004). Palich and Bagby (1995) and Koudstaal, Sloof, and Van Praag (2015) indicated that entrepreneurs are more optimistic and less psychologically vulnerable than non-entrepreneurs, and are less able to resist risks. Further, they indicated that non-entrepreneurs do not put as much effort into risk assessment and prevention. As a result, the optimism of entrepreneurs will cause them to misjudge situations and subsequently develop overconfidence. Therefore, this study proposes that:

$\mathbf{H}_{3}$ : Optimism has a positive effect on overconfidence; additionally, the path coefficient of males is higher than that of females.

Research has pointed out that optimism is usually evident among entrepreneurs during the early stage of ventures (Trevelyan, 2008), and is manifested in areas such as entrepreneurs' assessment of the probability of creating new ventures to commercialize products, the potential success of the venture, and investment prediction (Cassar, 2010): optimism would drive entrepreneurs to invest in high-risk ventures (Parker, 2006). Entrepreneurs' unique cognitive processes support their optimism and positive attitude toward the future (Palich \& Bagby, 1995), which contributes to them overlooking uncertainty and lowers their perception of the risks associated with new ventures. This discussion demonstrates how optimism serves as the best catalyst for the longevity and promise of new ventures (Seligman \& Schulman, 1986). Optimism is a stable personality trait unaffected by the external highly uncertain environment, which may lead to overestimating sales and underestimating potential risks in new business ventures, thus committing more entrepreneurial resources. On this basis, the following research hypothesis is formulated: 
H4: Optimism has a positive effect on entrepreneurial intentions; additionally, the path coefficient of males is higher than that of females.

Overconfident individuals overestimate the probability of particular outcomes (Zacharakis \& Shepherd, 2001) due to remembering only supportive viewpoints and failing to consider other evidence (Russo \& Schoemaker, 1992). This type of reasoning does not help improve the accuracy of useable information (Schwenk, 1986), and entrepreneurs' inability to collect relevant information will affect the quality of their decision-making (García-Sánchez, Rodríguez-Domínguez, \& Gallego-Álvarez, 2011). Such bias will lower entrepreneurs' perception of risks associated with new ventures (Zacharakis \& Shepherd, 2001). Based on some empirical pieces of evidence, Koellinger et al. (2007) argued that entrepreneurs must experience overconfidence; while Buttar (2015), and Bernoster, et al. (2018) pointed out how their overconfidence positively affects entrepreneurial intentions. Furthermore, Hayward et al. (2010) argued that a high level of confidence could stimulate positive emotions, increase entrepreneurs' resilience when facing obstacles, and encourage entrepreneurs to invest more in subsequent rounds. This study suggests that overconfident entrepreneurs are incredibly self-assured in their decision-making skills and, even in the face of uncertainty, are unable to acknowledge or change their erroneous decisions. This means that situations of uncertainty increase entrepreneurs' susceptibility to several cognitive biases (Baron, 1998). Such entrepreneurs may even have an active gambling mentality and believe the situation will change in their favor, which strengthens their confidence in new business ventures. Thus, the following hypothesis is formulated:

H5: Overconfidence has a positive effect on entrepreneurial intentions; additionally, the path coefficient of males is higher than that of females.

\section{Social Capital, Optimism, Overconfidence and Gender}

De Carolis and Saparito (2006) believed that social capital could affect cognitive bias, and provided empirical evidence that the level of entrepreneurs' social capital can increase their propensity to share and update their mental models, which in turn, affects their cognitive bias (De Carolis, Litzky, \& Eddleston, 2009; Buttar, 2015). Social capital, therefore, serves as an antecedent of cognitive factors.

For bonding social capital, trust is the principal mechanism (Nahapiet \& Ghoshal, 1998), which can further strengthen existing relationships in the community and contribute to the development of optimism and overconfidence in entrepreneurs. The information acquired from trusted partners tends to be perceived as accurate, which could lead to lack of verification, and subsequently, be overestimated as accurate 
(McEvily, Perrone, \& Zaheer, 2003). For aspiring, recently graduated entrepreneurs entering society, a stronger pool of bonding social capital is indicative of a stronger mutual trust mechanism. This mechanism is because bonding social capital with strong links can provide psychological support and comfort, allowing entrepreneurs to continue meeting challenges when difficulties and uncertainties emerge during the business creation process. The support of close friends encourages entrepreneurs to remain true to their original aspirations and increases their self-confidence. On this basis, the following hypotheses are developed:

H6: $_{6}$ Bonding social capital has a positive effect on optimism; additionally, the path coefficient of males is higher than that of females.

$\mathbf{H}_{7}$ : Bonding social capital has a positive effect on overconfidence; additionally, the path coefficient of males is higher than that of females.

Bridging social capital can increase the scope and diversity of information (Burt, 1992) accessible and help increase individuals' knowledge (Cohen \& Levinthal, 1990), but can lead to entrepreneurs' overestimating their knowledge base and contribute to the development of overconfidence and optimism. Furthermore, by relying on the support of this information network, entrepreneurs believe they can control uncertainty and further reap profits, making the pursuit of new ventures even more enticing. The one thing that young entrepreneurs lack the most, however, is personal connections. A heterogeneous pool of bridging social capital, though, will allow them to access an extensive and diverse range of information, become familiar with business venture circumstances, broaden their knowledge, and develop their awareness of the entrepreneurial environment. Subsequently, their optimistic assessment of the business environment and self-confidence as entrepreneurs will be enhanced. Thus, the following hypotheses are formulated:

H8: Bridging social capital has a positive effect on optimism; additionally, the path coefficient of males is higher than that of females.

H9: Bridging social capital has a positive effect on overconfidence; additionally, the path coefficient of males is higher than that of females.

The theory of social information processing emphasizes that members within the same groups could provide credible, critical information, and further influence others' attitudes or behavior at specific events. Salancik and Pfeffer (1978) indicated that people formulate their ideas based on the collected information from the environment surrounding them; that is, "whom you interact with people frequently, you could be 
influenced by them susceptible." Besides, interpersonal attraction theory posits that people with the same beliefs and values would always have a mutual attraction, thus reinforcing the shared attitude and behavior. Interpersonal attraction refers to the kind of attitude that they have a good impression between each other and are willing to develop friendship or affection. It is a definite form of interpersonal relationship (Tajfel \& Turner, 1986).

In conclusion, no matter the bonding or bridging social capital, people tend to make friends with similar persons. Through the agglomeration effect (Burt, 1992), the group to which a person belongs would shape his or her cognitive pattern (Moscovici, 1984). Meanwhile, people tend to speak a common language, accept the same belief and attitude simultaneously, or talk and listen to each other to accelerate information exchange and learning, prompting new business ventures. However, this mechanism also forms an information filter prompting a selective focusing effect to destroy the reality of information. This means that entrepreneurs might not recognize the real world; specifically, such filtering might cause them to overestimate the understanding of the real world to increase cognitive bias and the possibility of choosing to start up the new business. People who have a similar mindset would be together and overestimate the ability needed for specific tasks. They assert that they could control future events and choose to build up the new business. Thus, the following hypotheses are formulated:

H10a: $_{\text {B }}$ Bonding social capital has a positive effect on entrepreneurial intentions, which is mediated by optimism.

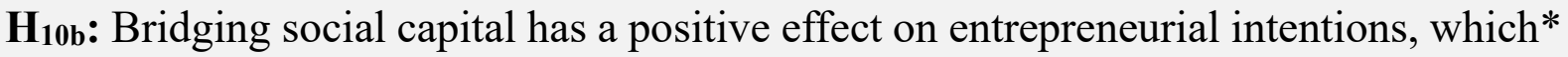
is mediated by optimism.

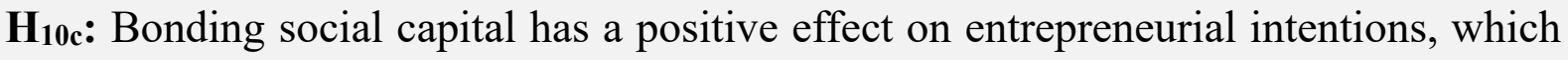
is mediated by overconfidence.

H10d: Bridging social capital has a positive effect on entrepreneurial intentions, which is mediated by overconfidence.

H10e: Bonding social capital has a positive effect on entrepreneurial intentions, which are mediated by optimism and overconfidence.

H10f: Bridging social capital has a positive effect on entrepreneurial intentions, which are mediated by optimism and overconfidence.

As mentioned earlier, past studies have less simultaneously combined the social resources and internal entrepreneurial mindset influence on entrepreneurial intentions and discussed their cause-effect relationships. On the other hand, few previous researches have discussed the gender differences of social capital and cognitive bias constructs in shaping entrepreneurial intentions. Thus, this research framework 
combines the SC-E model and entrepreneurial bias research to formulate a "social capital-cognitive bias-entrepreneurial intentions framework," seen in Figure 1. Social capital divides into bonding social capital and bridging social capital, and cognitive bias includes optimism and overconfidence. First, this study discusses the differences between gender in the relationship between social capital, cognitive bias, and entrepreneurial intentions. Then, it also explores the mediation effects of optimism and overconfidence.

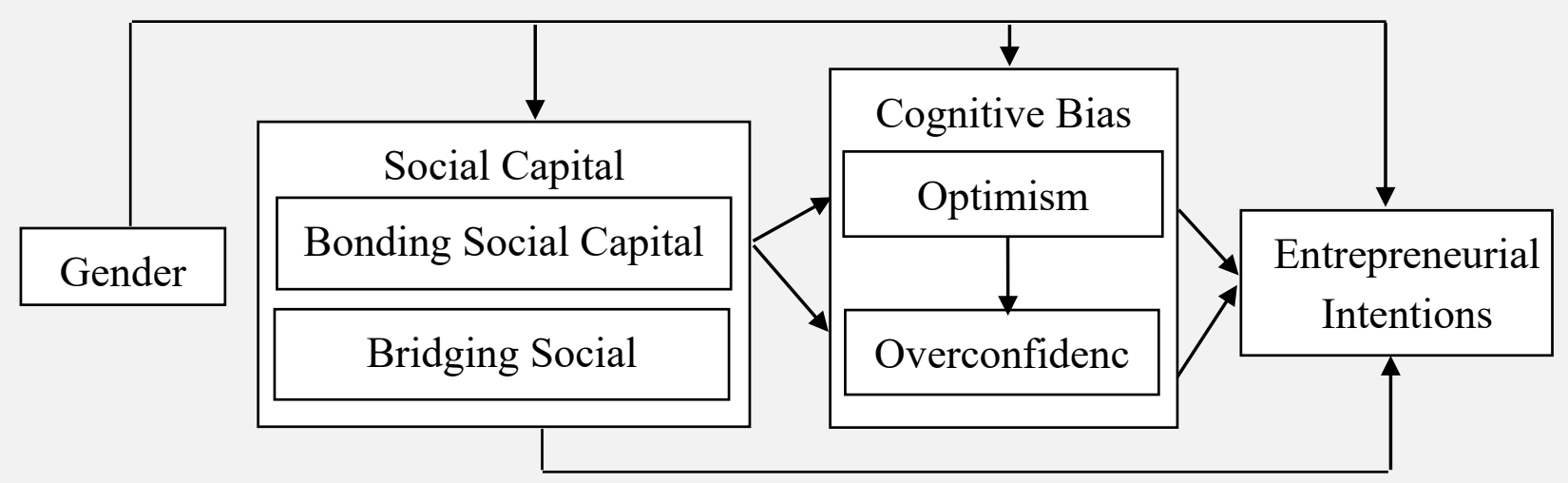

Figure 1 Research Framework

\section{Sample}

\section{METHODOLOGY}

This study involves a sample of 600 students, following many researchers examining the entrepreneurial intentions of university students (Liñán, Urbano, \& Guerrero, 2011; \& Buttar, 2015) The sample population is enrolled in at least one of the five entrepreneurship courses at a Taiwanese university. Data was collected through a self-administered questionnaire distributed during a class session. From a total of 600, 528 questionnaires were returned and subsequently screened for missing data and outliers (Hair, Black, Babin, Anderson, \& Tatham, 2006), leaving 511 useful questionnaires, equating to an effective response rate of $85.17 \%$. Among the responses received, males account for $56.8 \%, 53.6 \%$ of all respondents are aged 20 or under, and $29.7 \%$ are business college students.

\section{Measures}

Social capital includes the bonding and bridging types (Putnam, 2000), and all the questionnaire items are adapted from existing scales. This study separately uses ten items to measure bonding social capital and bridging social capital (Williams, 2006). Sample items are "There are several people online/offline I trust to help solve my problems," and "Interacting with people online/offline makes me feel like part of a 
larger community," and so on. Optimism is measured by ten items adapted from Scheier, Carver, and Bridges (1994); sample items include "In uncertain times, I usually expect the best" and "I am always optimistic about my future." A six-item overconfidence scale from Wilson et al. (2007) is used, with items worded as "I can be able to solve problems," "I can get people to agree with me," and so on. Six items are used to measure entrepreneurial intentions, adapted from Liñán et al. (2011); the items are worded as "I am ready to do anything to be an entrepreneur," and "I am determined to create a business venture in the future." Apart from the demographic characteristics of the student participants (including gender, age, and background), all the items are measured using a five-point Likert scale ( $1=$ strongly disagree; $5=$ strongly agree).

\section{Data analysis}

Testing the reliability of all the constructs, Cronbach's $\alpha$, composite reliability (CR), and corrected item-total correlation for each item are applied. This study applies confirmatory factor analysis (CFA), CR, and average variance extracted (AVE) (Lee, Cheung, \& Chen, 2007) to measure convergent validity. Besides, this study also uses AVE square root to measure discriminant validity. Data is analyzed using structural equation modeling (SEM) to test the hypotheses.

\section{RESULTS}

\section{Measurement Model}

Table 1 shows the items included in the measurement model in the full sample. Following the views of previous studies (Nunally, 1975; Hair et al., 2006), all corrected item-total correlations are greater than 0.35 (Nunally, 1975), except for $\mathrm{OP}_{3}(0.233)$; therefore, it is removed for later analysis. Cronbach's $\alpha$ is greater than 0.8, showing high reliability (Roberts \& Wortzel, 1979), while CR is greater than 0.7 (Chin, 1998). This analysis demonstrates adequate internal consistency.

This study applies CFA, CR, and AVE (Lee et al., 2007) to measure convergent validity. All items' factor loading is greater than $0.5, \mathrm{CR}$ of and all constructs are greater than 0.8, and AVE of all constructs are greater than 0.5 (Fornell \& Larcker, 1981). Additionally, this research uses AVE square root, which is the most strict method to measure discriminant validity. AVE square root has to be higher than the correlation coefficients for each pair of constructs (Fornell \& Larcker, 1981) (Table 2). The convergent and discriminant validities in this study are acceptable.

As all the measures of this study's variables are obtained from the same source, a procedure suggested by Chen, Lin, and Chen (2012) is followed to determine common method variances (CMV). Chen et al. (2012) stated that the goodness of fit for the CFA model is appropriate when all dimensions are divided into different factors, rather than 
combined into a single factor. In this paper, most five-factor loading exceeds 0.5 , and the number of five-factor loadings is higher than one-factor loading; Besides, CFA is conducted for five-factor and one-factor measurement models, the results of which indicate that the $\chi^{2}$ is low and goodness of fit appropriate for the five-factor model $\left(\chi^{2}(761)=2576.529, \mathrm{GFI}=0.825, \mathrm{AGFI}=0.809, \mathrm{RMSEA}=0.058, \mathrm{SRMR}=0.250\right)$, but respectively high and inadequate for the one-factor $\left(\chi^{2}(722)=4827.696\right.$, GFI $=0.592$, AGFI=0.537, RMSEA=0.106, SRMR=0.223). 
Table 1 Reliability and Validity Analysis

\begin{tabular}{|c|c|c|c|c|c|c|}
\hline Constructs & Items & $\begin{array}{l}\text { Corrected } \\
\text { Item-Total } \\
\text { Correlation }\end{array}$ & Cronbach's $\alpha$ & $\begin{array}{l}\text { Factor } \\
\text { Loading }\end{array}$ & $\mathrm{CR}$ & AVE \\
\hline \multirow{6}{*}{$\begin{array}{l}\text { Entrepreneurial } \\
\text { Intentions } \\
\text { (EI) }\end{array}$} & $\mathrm{EI}_{1}$ & 0.725 & \multirow{6}{*}{0.945} & 0.749 & \multirow{6}{*}{0.945} & \multirow{6}{*}{0.740} \\
\hline & $\mathrm{EI}_{2}$ & 0.850 & & 0.884 & & \\
\hline & $\mathrm{EI}_{3}$ & 0.846 & & 0.864 & & \\
\hline & $\mathrm{EI}_{4}$ & 0.853 & & 0.881 & & \\
\hline & $\mathrm{EI}_{5}$ & 0.856 & & 0.885 & & \\
\hline & $\mathrm{EI}_{6}$ & 0.867 & & 0.891 & & \\
\hline \multirow{10}{*}{$\begin{array}{l}\text { Bonding Social } \\
\text { Capital } \\
\text { (BOSC) }\end{array}$} & $\mathrm{BOSC}_{1}$ & 0.706 & \multirow{10}{*}{0.918} & 0.702 & \multirow{10}{*}{0.920} & \multirow{10}{*}{0.535} \\
\hline & $\mathrm{BOSC}_{2}$ & 0.672 & & 0.688 & & \\
\hline & $\mathrm{BOSC}_{3}$ & 0.708 & & 0.716 & & \\
\hline & $\mathrm{BOSC}_{4}$ & 0.709 & & 0.712 & & \\
\hline & $\mathrm{BOSC}_{5}$ & 0.596 & & 0.631 & & \\
\hline & $\mathrm{BOSC}_{6}$ & 0.770 & & 0.830 & & \\
\hline & $\mathrm{BOSC}_{7}$ & 0.748 & & 0.800 & & \\
\hline & $\mathrm{BOSC}_{8}$ & 0.647 & & 0.724 & & \\
\hline & $\mathrm{BOSC}_{9}$ & 0.691 & & 0.727 & & \\
\hline & BOSC $_{10}$ & 0.725 & & 0.767 & & \\
\hline \multirow{10}{*}{$\begin{array}{l}\text { Bridging Social } \\
\text { Capital } \\
\text { (BRSC) }\end{array}$} & $\mathrm{BRSC}_{1}$ & 0.712 & \multirow{10}{*}{0.940} & 0.727 & \multirow{10}{*}{0.938} & \multirow{10}{*}{0.605} \\
\hline & $\mathrm{BRSC}_{2}$ & 0.788 & & 0.817 & & \\
\hline & $\mathrm{BRSC}_{3}$ & 0.795 & & 0.840 & & \\
\hline & $\mathrm{BRSC}_{4}$ & 0.779 & & 0.817 & & \\
\hline & $\mathrm{BRSC}_{5}$ & 0.753 & & 0.786 & & \\
\hline & $\mathrm{BRSC}_{6}$ & 0.739 & & 0.750 & & \\
\hline & $\mathrm{BRSC}_{7}$ & 0.785 & & 0.792 & & \\
\hline & $\mathrm{BRSC}_{8}$ & 0.707 & & 0.704 & & \\
\hline & $\mathrm{BRSC}_{9}$ & 0.791 & & 0.798 & & \\
\hline & $\mathrm{BRSC}_{10}$ & 0.712 & & 0.732 & & \\
\hline \multirow{9}{*}{$\begin{array}{l}\text { Optimism } \\
\text { (OP) }\end{array}$} & $\mathrm{OP}_{1}$ & 0.622 & \multirow{9}{*}{0.808} & 0.730 & \multirow{9}{*}{0.900} & \multirow{9}{*}{0.510} \\
\hline & $\mathrm{OP}_{2}$ & 0.650 & & 0.780 & & \\
\hline & $\mathrm{OP}_{4}$ & 0.715 & & 0.850 & & \\
\hline & $\mathrm{OP}_{5}$ & 0.595 & & 0.650 & & \\
\hline & $\mathrm{OP}_{6}$ & 0.500 & & 0.570 & & \\
\hline & $\mathrm{OP}_{7}$ & 0.651 & & 0.781 & & \\
\hline & $\mathrm{OP}_{8}$ & 0.567 & & 0.670 & & \\
\hline & $\mathrm{OP}_{9}$ & 0.620 & & 0.741 & & \\
\hline & $\mathrm{OP}_{10}$ & 0.518 & & 0.560 & & \\
\hline \multirow{6}{*}{$\begin{array}{l}\text { Overconfidence }(\mathrm{O} \\
\mathrm{C})\end{array}$} & $\mathrm{OC}_{1}$ & 0.715 & \multirow[t]{6}{*}{0.873} & 0.753 & \multirow{6}{*}{0.869} & \multirow{6}{*}{0.528} \\
\hline & $\mathrm{OC}_{2}$ & 0.538 & & 0.606 & & \\
\hline & $\mathrm{OC}_{3}$ & 0.595 & & 0.662 & & \\
\hline & $\mathrm{OC}_{4}$ & 0.714 & & 0.795 & & \\
\hline & $\mathrm{OC}_{5}$ & 0.715 & & 0.745 & & \\
\hline & $\mathrm{OC}_{6}$ & 0.748 & & 0.777 & & \\
\hline
\end{tabular}


Table 2 AVE Square Root and Correlation Coefficients Matrix

\begin{tabular}{|c|c|l|l|l|l|}
\hline Constructs & EI & BOSC & BRSC & OP & OC \\
\hline EI & $\mathbf{0 . 8 6 0}$ & & & & \\
\hline BOSC & $0.268 * * *$ & $\mathbf{0 . 7 6 1}$ & & & \\
\hline BRSC & $0.260 * * *$ & $0.754 * * *$ & $\mathbf{0 . 7 7 8}$ & & \\
\hline OP & $0.420 * * *$ & $0.446 * * *$ & $0.467 * * *$ & $\mathbf{0 . 5 7 1}$ & \\
\hline OC & $0.397 * * *$ & $0.419 * * *$ & $0.420 * * *$ & $0.568^{* * *}$ & $\mathbf{0 . 7 2 7}$ \\
\hline
\end{tabular}

Note: 1.Diagonal are AVE Square Root, the others are correlation coefficients.

2. ${ }^{*} \mathrm{p}<0.05, * * \mathrm{p}<0.01, * * * \mathrm{p}<0.001$.

\section{Hypotheses Testing}

First, this paper measures the proposed structural model with the goodness of fit statistics, which show that overall, it fits the data quite well $\left(\chi^{2}(750)=1668.302, p\right.$ $=0.00$, GFI $=0.858$, AGFI $=0.837$, PGFI $=0.747$, RMSEA $=0.049$, RMR $=0.052$ ) (Mulaik, James, Van Alstine, Bennett, Lind, \& Stilwell, 1989; Hair et al. 2006).

This study tests the paths among all the constructs and makes a comparison between males and females (Table 3). As for $\mathrm{H}_{1}$ and $\mathrm{H}_{2}$, bonding social capital has a positive effect on entrepreneurial intentions $(\beta=0.150, p>0.05)$ in the full sample and bridging social capital has a negative effect on entrepreneurial intentions in the full sample $(\beta=-0.124, \mathrm{p}>0.05)$; therefore, both do not reach significance, thus $\mathrm{H}_{1}$ and $\mathrm{H}_{2}$ are not supported. The negative effect of bridging social capital on entrepreneurial intentions may be due to information-overloaded, which on the contrary, hinders the intention to start a new business. In the two subsamples, the paths of social capital effect also do not reach significance.

The impact of optimism on overconfidence is positive in the full sample and two subsamples; the path coefficient of males is lower than that of females $(\beta=0.564, p<$ $0.001 ; \beta$ male $=0.468, \mathrm{p}<0.001 ; \beta$ female $=0.695, \mathrm{p}<0.001$, respectively $)$. Both optimism and overconfidence have a positive and significant effect on entrepreneurial intentions $(\beta=0.646, p<0.001 ; \beta$ male $=0.507, p<0.01 ; \beta$ female $=0.649, p<0.001$, respectively $)$ $(\beta=0.402, p<0.01 ; \beta$ male $=0.679, p<0.001 ; \beta$ female $=0.211, p>0.05$, respectively $)$ in the full sample and two subsamples. However, the path "OP $\rightarrow \mathrm{EI}$ " in males is lower than that of females. The path "OC $\rightarrow$ EI" reaches statistical significance ( $\beta$ male $=0.679$, $\mathrm{p}<0.001)$ in the male subgroup. This implies that overconfidence does not affect women's intentions to start a business. These results partly support $\mathrm{H}_{3}$ and $\mathrm{H}_{4}$, and fully support $\mathrm{H}_{5}$.

Investigating $\mathrm{H}_{6}$, bonding social capital has a significant positive effect on optimism in the full sample and subsamples; the path coefficient of males is lower than that of females $(\beta=0.258, p<0.001 ; \beta$ male $=0.240, p<0.05 ; \beta$ female $=0.278, p<0.05$, 
respectively). Thus, $\mathrm{H}_{6}$ is partly supported. However, the effect of bonding social capital on overconfidence does not reach a statistically significant level; thus, $\mathrm{H}_{7}$ is not supported. In the female subsample, bonding social capital has a negative effect on overconfidence.

The impact of bridging social capital on optimism is significant and positive $(\beta=0.249, \mathrm{p}<0.01)$, and also significantly positive on overconfidence $(\beta=0.147, \mathrm{p}<$ 0.01) in the full sample. Comparing the differences between males and females, both paths "BRSC $\rightarrow$ OP" ( $\beta$ male $=0.241, p<0.001 ; \beta$ female $=0.273, p<0.05$, respectively $)$, and "BRSC $\rightarrow$ OC" $(\beta$ male $=0.066, p>0.05 \beta$ female $=0.304, p<0.05$, respectively $)$ in males are lower than that of females. These results partly support $\mathrm{H}_{8}$ and $\mathrm{H}_{9}$.

Table 3 Total Effects in the Full Samples and the Male and Female Subsamples

\begin{tabular}{|c|c|c|c|c|}
\hline Path Coefficients & Full Sample $\beta(\mathrm{t})$ & Male $\beta(\mathrm{t})$ & Female $\beta(\mathrm{t})$ & Hypothesis \\
\hline BOSC $\rightarrow$ EI & $0.150(1.031)$ & $0.165(0.947)$ & $0.133(0.567)$ & $\mathrm{H}_{1}$ \\
\hline BRSC $\rightarrow$ EI & $-0.124(-0.876)$ & $0.004(0.024)$ & $-0.265(-1.042)$ & $\mathrm{H}_{2}$ \\
\hline OP $\rightarrow$ OC & $0.564(8.302)^{* * *}$ & $0.468(5.897)^{* * *}$ & $0.695(6.093)^{* * *}$ & $\mathrm{H}_{3}$ \\
\hline OP $\rightarrow$ EI & $0.646(4.324)^{* * *}$ & $0.507(2.792)^{* *}$ & $0.649(2.762)^{* * *}$ & $\mathrm{H}_{4}$ \\
\hline OC $\rightarrow$ EI & $0.402(2.904)^{* *}$ & $0.679(3.269)^{* * *}$ & $0.211(1.182)$ & $\mathrm{H}_{5}$ \\
\hline BOSC $\rightarrow$ OP & $0.258(3.177)^{* * *}$ & $0.240(2.354)^{*}$ & $0.278(2.149)^{*}$ & $\mathrm{H}_{6}$ \\
\hline BOSC $\rightarrow$ OC & $0.011(0.158)$ & $0.049(0.628)$ & $-0.09(-0.723)$ & $\mathrm{H}_{7}$ \\
\hline BRSC $\rightarrow$ OP & $0.249(3.154)^{* *}$ & $0.241(2.597)^{* * *}$ & $0.273(1.989)^{*}$ & $\mathrm{H}_{8}$ \\
\hline BRSC $\rightarrow$ OC & $0.147(2.164)^{* *}$ & $0.066(0.928)$ & $0.304(2.273)^{*}$ & $\mathrm{H}_{9}$ \\
\hline $\mathrm{BOSC} \rightarrow$ OP $\rightarrow$ EI & 0.167 & 0.122 & 0.180 & $\mathrm{H}_{10 \mathrm{a}}$ \\
\hline $\mathrm{BRSC} \rightarrow$ OP $\rightarrow$ EI & 0.161 & 0.122 & 0.177 & $\mathrm{H}_{10 \mathrm{~b}}$ \\
\hline $\mathrm{BOSC} \rightarrow$ OC $\rightarrow$ EI & 0.004 & 0.033 & -0.019 & $\mathrm{H}_{10 \mathrm{c}}$ \\
\hline $\mathrm{BRSC} \rightarrow$ OC $\rightarrow$ EI & 0.059 & 0.045 & 0.064 & $\mathrm{H}_{10 \mathrm{~d}}$ \\
\hline $\mathrm{BOSC} \rightarrow$ OP $\rightarrow$ OC $\rightarrow$ EI & 0.058 & 0.076 & 0.041 & $\mathrm{H}_{10 \mathrm{e}}$ \\
\hline $\mathrm{BRSC} \rightarrow$ OP $\rightarrow$ OC $\rightarrow$ EI & 0.056 & 0.077 & 0.040 & $\mathrm{H}_{10 \mathrm{f}}$ \\
\hline
\end{tabular}

Note: ${ }^{*} \mathrm{p}<0.05,{ }^{* *} \mathrm{p}<0.01,{ }^{* * *} \mathrm{p}<0.001$.

This paper adopts the technique introduced by Sobel (1982) to confirm the mediation effect. The indirect effect should be taking into account with the following: "independent variable $\rightarrow$ mediator variable $\rightarrow$ dependent variable," of which the value of the standardized path coefficient for both paths should be multiplied. Following 
Baron and Kenny (1986), which inherits from Sobel (1982), the indirect effect should be higher than the direct effect to indicate the mediating effect has occurred in SEM. This research finds that in the relationship of $\mathrm{BOSC} \rightarrow \mathrm{OP} \rightarrow \mathrm{EI}$, the indirect effect in the full sample and female subsample $(\beta=0.258 * 0.646=0.167 ; \beta$ male $=0.240 * 0.507=0.122$; $\beta$ female $=0.278 * 0.649=0.180$, respectively) is higher than the direct effect ( $\beta=0.150 ; \beta$ male $=0.165 ; \beta$ female $=0.133$, respectively). Additionally, in the relationship of $\mathrm{BRSC} \rightarrow \mathrm{OP} \rightarrow \mathrm{EI}$, the indirect effect in the full sample and male subsample $(\beta=0.161 ; \beta$ male $=0.122 ; \beta$ female $=0.177$, respectively $)$ is higher than the direct effect $(\beta=-0.124 ; \beta$ male $=0.004 ; \beta$ female $=-0.265$, respectively), implying that optimism has a positive mediating relationship between bonding social capital, bridging social capital and entrepreneurial intentions. This supports $\mathrm{H}_{10 a}$ and $\mathrm{H}_{10 b}$. Investigating $\mathrm{H}_{10 c}$, the indirect effect in the full sample and subsamples $(\beta=0.004 ; \beta$ male $=0.033 ; \beta$ female $=-0.019$, respectively) is lower than the direct effect $(\beta=0.150 ; \beta$ male $=0.165 ; \beta$ female $=0.133$, respectively); thus, $\mathrm{H}_{10 \mathrm{c}}$ is unsupported. However, the mediating effect of overconfidence between bridging social capital and entrepreneurial intentions shows an indirect effect in the male subsample ( $\beta$ male $=0.045)$, which is higher than the direct effect $(\beta$ male $=0.004)$, thus supporting $\mathrm{H}_{10 \mathrm{~d}}$.

In $\mathrm{H}_{10 \mathrm{e}}$ and $\mathrm{H}_{10 \mathrm{f}}$, the mediating effects of optimism and overconfidence between bonding social capital and entrepreneurial intentions show an indirect effect of the full sample and subsamples $(\beta=0.058 ; \beta$ male $=0.076 ; \beta$ female $=0.041$, respectively $)$, which are lower than the direct effect $(\beta=0.150 ; \beta$ male $=0.165 ; \beta$ female $=0.133$, respectively $)$. Thus, $\mathrm{H}_{10 \mathrm{e}}$ is unsupported. In BRSC $\rightarrow \mathrm{OP} \rightarrow \mathrm{OC} \rightarrow \mathrm{EI}$, the indirect effect in the male subsample $(\beta$ male $=0.077)$ is higher than the direct effect $(\beta$ male $=0.004)$, supporting $\mathrm{H}_{10 f}$.

Table 4 MANOVA to Test Differences between Male and Female ${ }^{1}$

\begin{tabular}{|c|c|c|c|c|}
\hline Constructs & Gender & Mean & SD & \multirow{2}{*}{$\mathrm{F}_{(1,509)}$} \\
\hline \multirow{2}{*}{ Entrepreneurial intentions } & Male & 3.756 & 1.522 & \multirow{2}{*}{$23.780^{* * *}$} \\
\cline { 2 - 4 } & Female & 3.137 & 1.283 & \\
\hline \multirow{2}{*}{ Bonding social capital } & Male & 3.373 & 0.721 & \multirow{2}{*}{0.310} \\
\cline { 2 - 4 } & Female & 3.410 & 0.765 & \\
\hline \multirow{2}{*}{ Bridging social capital } & Male & 3.632 & 0.717 & \multirow{2}{*}{0.079} \\
\cline { 2 - 4 } & Female & 3.614 & 0.707 & \\
\hline \multirow{2}{*}{ Optimism } & Male & 3.500 & 0.590 & \multirow{2}{*}{$6.049 *$} \\
\cline { 2 - 4 } & Female & 3.370 & 0.555 & \\
\hline \multirow{2}{*}{ Overconfidence } & Male & 3.666 & 0.624 & \multirow{2}{*}{2.510} \\
\cline { 2 - 4 } & Female & 3.572 & 0.712 & \\
\hline
\end{tabular}

Note: $1 . \mathrm{F}_{(5,505)}=5.667, \mathrm{p}<0.001$, Wilks' Lambda $=0.947, \mathrm{SD}=$ Standard Deviation.

2. $* \mathrm{p}<0.05, * * \mathrm{p}<0.01, * * * \mathrm{p}<0.001$. 
After hypotheses testing, the MANOVA is proposed to compare the scores obtained in the five constructs by male and female students (Table 4). The results show a statistically significant difference between the two groups for the combined dependent variables $\left(\mathrm{F}_{(5,505)}=5.667, \mathrm{p}<0.001\right.$, Wilks' Lambda $\left.=0.947\right)$. Then, the model is tested separately in each male and female subsample to test for differences in their means. The results show that male students display higher levels of entrepreneurial intentions $\left(\mathrm{F}_{(1}\right.$, 509) $=23.780, \mathrm{p}<0.001$, Mean male $=3.756>$ Mean female $=3.137)$ and optimism $\left(\mathrm{F}_{(1,}\right.$ 509) $=6.049, \mathrm{p}<0.05$, Mean male $=3.500>$ Mean female=3.370) than female students. Besides, there are no differences in the levels of bonding social capital, bridging social capital, and overconfidence in the two subsamples. Overall, the results indicate that male students are more optimistic (relative stability of personality traits) and have higher entrepreneurial intentions than females.

\section{Discussion}

\section{CONCLUSION}

This research combines the SC-E model and entrepreneurial bias research to formulate a "social capital-cognitive bias-entrepreneurial intentions framework," to discuss the differences between gender in the relationship among social capital, cognitive bias, and entrepreneurial intentions. Besides, it also explores the mediation effects of optimism and overconfidence. The results of hypotheses testing are shown in Table 5.

First, the empirical results show that bonding social capital has a positive effect on entrepreneurial intentions in the full sample and subsamples while bridging social capital has a negative effect on entrepreneurial intentions in the full sample and female sample. The negative effect of bridging social capital on entrepreneurial intentions may be due to information overload; on the contrary, it hinders the intention to start a new business. Besides, in the female subsample, bridging social capital on entrepreneurial intentions having a negative impact might be due to their characteristics. Women are obedient, kindly and peaceful, and have had fewer management experiences (Brush et al., 2004). They are afraid of being the entrepreneur and to make decisions, even though bridging social capital could accumulate new information or knowledge from different groups; therefore, women prefer to be risk-averse.

Second, The empirical results indicate that optimism has a significant positive effect on overconfidence, which is consistent with the findings of Gudmundsson and Lechner (2013). It is our contribution to distinguish between optimism and overconfidence, and clarify their effects on entrepreneurial intentions. Both optimism and overconfidence have a significant positive effect on entrepreneurial intentions, but overconfidence has an insignificant positive impact on entrepreneurial intentions in the 
female subgroup. The reason discussed is that the female is considered to have fewer network resources (Becker-Blease \& Sohl, 2007) and less management experience (Brush et al., 2004). However, overconfidence is a reaction to specific situations (Griffin \& Varey, 1996); specifically, running a new business is a complicated and specific situation. To summarize the explanations above, overconfidence has an insignificant positive impact on entrepreneurial intentions in the female subgroup. This finding indicates that the positive and optimistic attitude of entrepreneurs can stimulate positive emotions so that, despite the high level of stress associated with creating new ventures, entrepreneurs can still achieve their entrepreneurial goals: The positive energy within entrepreneurs helps them to accomplish whatever they set their minds to. Optimism is a fundamental psychological catalyst for entrepreneurship.

Third, the empirical results show that bonding social capital could yield a significantly positive effect only on optimism, and it has a negative impact on overconfidence in the female subsample. Meanwhile, bridging social capital has an impact on both optimism and overconfidence in both genders. This study considers optimism to be a stable personality trait in all situations (Trevelyan, 2008) that could affect emotions and behaviors (Lounsbury et al., 2004), underpinned by bonding social capital, which, through the mechanism of trust (Nahapiet \& Ghoshal, 1998), can strengthen existing relationships and provide emotional support within a community. In turn, it can allow the information acquired from trusted partners to be perceived as accurate. However, overconfidence is a transitory cognitive process that affects thinking about specific tasks. Female students, even with the positive support of their families and friends, still doubt whether they can accomplish the new business goal, thus decreasing their degree of confidence. Whereas bridging social capital can increase the scope and diversity of information and knowledge, making it more widely available (Cohen \& Levinthal, 1990), it also provides a more prosperous social network and allows entrepreneurs to believe they can control uncertainty. By updating their mental models, entrepreneurs become more optimistic, and due to overestimating the accuracy of their knowledge, overconfident. These empirical results concur with the findings of De Carolis and Saparito (2006), De Carolis et al. (2009), and Buttar (2015), in that entrepreneurs' social capital is an essential contributor to their cognitive bias. Entrepreneurs should thus broaden their contacts and build networks with different communities to increase the scope and diversity of the information that is accessible, thereby increasing their positive attitude toward the outcome of ventures.

Fourth, two types of social capital affect entrepreneurial intentions through two cognitive biases: Optimism and overconfidence. This finding explains why social networks alone can not accelerate the development of new ventures. External factors, such as bonding social capital, could, through internal factors, such as optimism, affect 
entrepreneurial intentions, while the other external factor of bridging social capital could, through two internal factors, optimism and overconfidence, affect entrepreneurial intentions. This means that if entrepreneurs own two types of social capital with an optimistic personality, it could increase their entrepreneurial intentions. Entrepreneurs' own bridging social capital with overconfidence could also boost entrepreneurial intentions. Because bridging social capital is based on the agglomeration effect (Burt, 1992), the group would shape the cognitive pattern of the person (Moscovici, 1984). Besides, according to the theory of social information processing and interpersonal attraction theory, the members within the same groups through a universal language, can accelerate information exchange, learn how to increase their optimism, and establish their overconfidence, which also prompts the development of the new business.

Finally, the results indicate that males scored significantly higher than females in entrepreneurial intentions and optimism, but there was no difference in social capital (both bonding \& bridging) and overconfidence. This may be partly due to the fact that optimism has been thought to be a personality trait related to positive expectations regarding future events that are relatively stable over time (natural-born) and across situations, while overconfidence is just a reaction to specific events. Table 4 shows that male students are more optimistic than females and can cope better when faced with obstacles and challenging situations; they also have stronger intentions to pursue an entrepreneurial career. 
Table 5 Results of Hypotheses Testing

\begin{tabular}{|c|c|}
\hline Hypothesis & Results \\
\hline $\begin{array}{l}\mathrm{H}_{1} \text { : Bonding social capital has a positive effect on entrepreneurial } \\
\text { intentions; additionally, the path coefficient of males is higher than that } \\
\text { of females. }\end{array}$ & Not Supported \\
\hline $\begin{array}{l}\mathrm{H}_{2} \text { : Bridging social capital has a positive effect on entrepreneurial } \\
\text { intentions; additionally, the path coefficient of males is higher than } \\
\text { that of females. }\end{array}$ & Not Supported \\
\hline $\begin{array}{l}\mathrm{H}_{3} \text { : Optimism has a positive effect on overconfidence; additionally, the } \\
\text { path coefficient of males is higher than that of females. }\end{array}$ & $\begin{array}{c}\text { Partly } \\
\text { Supported }\end{array}$ \\
\hline $\begin{array}{l}\mathrm{H}_{4}: \text { Optimism has a positive effect on entrepreneurial intentions; } \\
\text { additionally, the path coefficient of males is higher than that of females. }\end{array}$ & $\begin{array}{c}\text { Partly } \\
\text { Supported }\end{array}$ \\
\hline $\begin{array}{l}\mathrm{H}_{5} \text { : Overconfidence has a positive effect on entrepreneurial intentions; } \\
\text { additionally, the path coefficient of males is higher than that of females. }\end{array}$ & Supported \\
\hline $\begin{array}{l}\mathrm{H}_{6} \text { : Bonding social capital has a positive effect on optimism; additionally, } \\
\text { the path coefficient of males is higher than that of females. }\end{array}$ & $\begin{array}{l}\text { Partly } \\
\text { Supported }\end{array}$ \\
\hline $\begin{array}{l}\mathrm{H}_{7} \text { : Bonding social capital has a positive effect on overconfidence; } \\
\text { additionally, the path coefficient of males is higher than that of females. }\end{array}$ & Not Supported \\
\hline $\begin{array}{l}\text { H8: Bridging social capital has a positive effect on optimism; additionally, } \\
\text { the path coefficient of males is higher than that of females. }\end{array}$ & $\begin{array}{c}\text { Partly } \\
\text { Supported }\end{array}$ \\
\hline $\begin{array}{l}\text { H9: Bridging social capital has a positive effect on overconfidence; } \\
\text { additionally, the path coefficient of males is higher than that of females. }\end{array}$ & $\begin{array}{c}\text { Partly } \\
\text { Supported }\end{array}$ \\
\hline 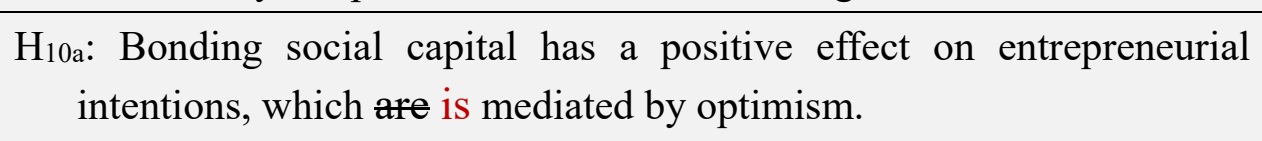 & Supported \\
\hline $\begin{array}{l}\text { H10b: Bridging social capital has a positive effect on entrepreneurial } \\
\text { intentions, which are is mediated by optimism. }\end{array}$ & Supported \\
\hline $\begin{array}{l}\mathrm{H}_{10 c} \text { : Bonding social capital has a positive effect on entrepreneurial } \\
\text { intentions, which are is mediated by overconfidence. }\end{array}$ & Not Supported \\
\hline $\begin{array}{l}\mathrm{H}_{10 \mathrm{~d}} \text { Bridging social capital has a positive effect on entrepreneurial } \\
\text { intentions, which are is mediated by overconfidence. }\end{array}$ & Supported \\
\hline $\begin{array}{l}\mathrm{H}_{10 \mathrm{e}} \text { : Bonding social capital has a positive effect on entrepreneurial } \\
\text { intentions, which are mediated by optimism and overconfidence. }\end{array}$ & Not Supported \\
\hline $\begin{array}{l}\text { H10f: Bridging social capital has a positive effect on entrepreneurial } \\
\text { intentions, which are mediated by optimism and overconfidence. }\end{array}$ & Supported \\
\hline
\end{tabular}

Díaz-García et al. (2010) used the theory of planned behavior to discuss the relationship between gender and entrepreneurial intentions. However, this study in a more comprehensive perspective, and integrates the SC-E model and entrepreneurial bias research, focusing on the gender differences between social capital and cognitive 
bias constructs, such as optimism, overconfidence, and entrepreneurial intentions. The empirical results concur with Díaz-García et al. (2010) and indicate that gender plays a key role in entrepreneurial issues. Besides, this research has other contributions which Díaz-García et al. (2010) have not discussed. First, it finds that when female entrepreneurs boost optimism, they are more overconfident and want to build up the new business more than males. Meanwhile, the more bonding social capital and bridging social capital female entrepreneurs own, the more optimism they have. Furthermore, when women have more bridging social capital, they could be more overconfident. Finally, male students are more optimistic, have higher entrepreneurial intentions than females, and thus, have the confidence to create new ventures.

\section{Managerial Implications}

First, the empirical implication of this study is that a combination of optimistic attitudes and overconfident behaviors are necessary for entrepreneurial intentions; further, external social capital affects entrepreneurial intentions, which are mediated by these internal two cognitive biases. Only the cognitive bias triggered by optimism and overconfidence can positively affect entrepreneurial intentions, as well as abundant social networks and information; further, entrepreneurs also need positive attitudes, self-belief, and an optimistic outlook before they can fearlessly embark on the challenging journey of entrepreneurship.

Secondly, entrepreneurship is essentially a tug of war between resources and state of mind. To maintain a high level of energy and sustain new ventures, entrepreneurs should continuously examine not only their social information, but also the type and source of their resources, as well as identify distinct traits in each type of social capital, and recognize how they assess risks, uncertainty, and outcomes.

Third, recently, an increasing number of women are willing to set up new ventures to become an entrepreneur due to environmental and characteristic factors. Female entrepreneurs could participate in different groups to accelerate new resources and information and broaden their minds to accept new knowledge. In this situation, the environment is friendly and suitable for females to build up their own company. Even facing difficult situations, female entrepreneurs can think more considerately and deeply than males and handle these situations well because of their gentle and circumspect personality. It implies that encouraging females to own social capital will boost their optimism traits and increase overconfidence to create new ventures. Thus, when fostering potential entrepreneurs, corporations, universities, and government agencies should recognize that optimism and overconfidence are not "bad," but rather beneficial when deciding to become an entrepreneur. Optimism and overconfidence both could accelerate the foundation of new ventures as well as drive quick and 
adequate decision-making in the face of uncertainty. Therefore, stable mental models could influence confidence levels in particular situations; additionally, entrepreneurs should maintain their optimism to make the correct decisions.

Finally, corporations may wish to explore whether potential entrepreneurs have the trait of optimism; however, it is a relatively stable personality trait, and can not be cultivated overnight. Thus, corporations could group entrepreneurs with this trait into teams and assign projects to provide opportunities for individuals to learn from one another and develop personally. Furthermore, corporations could run new courses on social psychology to help potential entrepreneurs identify environmental uncertainties and understand their state of mind when making decisions. Concerning bridging social capital, corporations could encourage potential entrepreneurs to diversify their circle of friends and broaden their resources with such strategies as hosting forums for sharing experiences and creating counseling centers. Besides, a virtual social-networking site could collect valuable information to enhance entrepreneurial intentions.

\section{Limitations and Future Research}

There are some limitations to this study. First, this study only discusses the relationship between entrepreneurial determinants and entrepreneurial intentions. Future research could explore the actual new venture action when students graduate from the university campus and the changed situation between social capital and cognitive bias. Second, there is currently no consensus on the measurement of social capital. Future studies could explore which type of social capital is most relevant to entrepreneurship. Third, this study involves a sample of 511 Taiwanese university students, only from a single country. Comparative research designs covering different countries could be conducted in the future. Finally, this study only selects the most representative variables of cognitive bias: Optimism and overconfidence. However, there was a minute amount of literature discussing entrepreneur characteristics and how this is related to their psychology. It is therefore suggested that future research focus on other psychological characteristics when discussing the relationships between social capital and entrepreneurial intentions.

\section{REFERENCES}

Adler, P., \& Kwon, S. (2002). Social capital: Prospects for a new concept. Academy of Management Review, 27(1), 17-40. https://doi.org/10.5465/amr.2002.5922314

Arenius, P., \& Minniti, M. (2005). Perceptual variables and nascent entrepreneurship. Small Business Economics, 24(3), 233-247.

https://doi.org/10.1007/s11187-005-1984-X

Asante, E. A., and Affum-Osei, E. (2019). Entrepreneurship as a career choice: The 
impact of locus of control on aspiring entrepreneurs' opportunity recognition. Journal of Business Research, 98, 227-235.

https://doi.org/10.1016/j.jbusres.2019.02.006

Barber, B. M., \& Odean, T. (2001). Boys will be boys: Gender, overconfidence, and common stock investment. The Quarterly Journal of Economics, 116(1), 261-292. https://doi.org/10.1162/003355301556400

Baron, R. A. (1998). Cognitive mechanisms in entrepreneurship: Why and when enterpreneurs think differently than other people. Journal of Business Venturing, 13(4), 275-294. https://doi.org/10.1016/S0883-9026(97)00031-1

Baron, R. A., \& Tang, J. (2009). Entrepreneurs' social skills and new venture performance: Mediating mechanisms and cultural generality. Journal of Management, 35(2), 282-306. https://doi.org/10.1177/0149206307312513

Baron, R. M., \& Kenny, D. A. (1986). The moderator-mediator variable distinction in social psychological research: Conceptual, strategic, and statistical considerations. Journal of Personality and Social Psychology, 51(6), 1173. https://doi.org/00223514/86/S00.75

Bauernschuster, S., Falck, O., \& Heblich, S. (2010). Social capital access and entrepreneurship. Journal of Economic Behavior \& Organization, 76, 821-833. https://doi.org/10.1016/j.jebo.2010.09.014

Becker-Blease, J. R., \& Sohl, J. E. (2007). Do women-owned businesses have equal access to angel capital?. Journal of Business Venturing, 22(4), 503-521. https://doi.org/10.1016/j.jbusvent.2006.06.003

Bem, S. L. (1981). Gender schema theory: A cognitive account of sex typing. Psychological Review, 88(4), 354-364. http://dx.doi.org/10.1037/0033-295X.88.4.354

Bernoster, I., Rietveld, C., Thurik, A., \& Torrès, O. (2018). Overconfidence, optimism and entrepreneurship. Sustainability, 10(7), 1-14.

https://doi.org/10.3390/su10072233

Bird, B. (1988). Implementing entrepreneurial ideas: The case for intention. Academy of Management Review, 13(3), 442-453.

https://doi.org/10.5465/amr.1988.4306970

Brüderl J., \& Preisendorfer, P. (1998). Network support and the success of newly founded businesses. Small Business Economics, 10(3), 213-225. https://doi.org/10.1023/A:100799710

Brush, C., Carter, N., Gatewood, E., Greene, P., \& Hart, M. (2004). Clearing the hurdles: Women building high-growth businesses. F T Press.

Burt, R. S. (1992). Structural holes: The social structure of competition. Harvard University Press. 
Burt, R. S. (2005). Brokerage and closure: An introduction to social capital. London: Oxford University Press.

Buttar, H. M. (2015). Retracted formation of entrepreneurial career intentions: The role of sociocognitive factors. Journal of Employment Counseling, 52(1), 2-17. https://doi.org/10.1002/j.2161-1920.2015.00052.x

Cassar, G. (2010). Are individuals entering self-employment overly optimistic? An empirical test of plans and projections on nascent entrepreneur expectations. Strategic Management Journal, 31(8), 822-840. https://doi.org/10.1002/smj.833

Chen, C. C., Lin, M. M., \& Chen, C. M. (2012). Exploring the mechanisms of the relationship between website characteristics and organizational attraction. The International Journal of Human Resource Management, 23(4), 867-885. https://doi.org/10.1080/09585192.2011.579916

Chin, W. W. (1998). Commentary: Issues and opinions on structural equation modeling. MIS Quarterly, 22(1), 7-16. https://www.jstor.org/stable/249674

Cohen, W., \& Levinthal, D. (1990). Absorptive capacity: A new perspective on learning and innovation. Administrative Science Quarterly, 35(1), 128-152. https://doi.org/10.2307/2393553

Coleman, J. S. (1988). Social capital in the creation of human capital. The American Journal of Sociology, 94, S95-S120.

Davies-Netzley, S. A. (1998). Women above the glass ceiling: Perceptions on corporate mobility and strategies for success. Gender and Society, 12(3), 339-355. https://doi.org/10.1177/0891243298012003006

De Carolis, D. M., \& Saparito, P. (2006). Social capital, cognition, and entrepreneurial opportunities: A theoretical framework. Entrepreneurship Theory and Practice, 30(1), 41-56. https://doi.org/10.1111/j.1540-6520.2006.00109.x

De Carolis, D. M., Litzky, B. E., \& Eddleston, K. A. (2009). Why networks enhance the progress of new venture creation: The influence of social capital and cognition. Entrepreneurship Theory and Practice, 33(2), 527-545. https://doi.org/10.1111/j.1540-6520.2009.00302.x

Díaz-García, M. C., \& Jiménez-Moreno, J. (2010). Entrepreneurial intention: The role of gender. International Entrepreneurship and Management Journal, 6(3), 261283. https://doi.org/10.1007/s11365-008-0103-2

Espíritu-Olmos, R., \& Sastre-Castillo, M. A. (2015). Personality traits versus work values: Comparing psychological theories on entrepreneurial intention. Journal of Business Research, 68(7), 1595-1598.

https://doi.org/10.1016/j.jbusres.2015.02.001

Fayolle, A., \& Liñán, F. (2014). The future of research on entrepreneurial intentions. Journal of Business Research, 67(5), 663-666. 
https://doi.org/10.1016/j.jbusres.2013.11.024

Fornell, C., \& Larcker, D. F. (1981). Evaluating structural equation models with unobservable variables and measurement error. Journal of Marketing Research, 18(1), 39-50. https://doi.org/10.1177/002224378101800104

Garbarino, E., \& Strahilevitz, M. (2004). Gender differences in the perceived risk of buying online and the effects of receiving a site recommendation. Journal of Business Research, 57(7), 768-775.

https://doi.org/10.1016/S0148-2963(02)00363-6

García-Sánchez, I. M., Rodríguez-Domínguez, L., \& Gallego-Álvarez, I. (2011). The relationship between political factors and the development of e-participatory government. The Information Society, 27(4), 233-251.

https://doi.org/10.1080/01972243.2011.583816

Giacomin, O., Janssen, F., \& Shinnar, R. S. (2016). Student entrepreneurial optimism and overconfidence across cultures. International Small Business Journal, 34(7), 925-947. https://doi.org/10.1177/0266242616630356

Goldstein, D. G., \& Gigerenzer, G. (2002). Models of ecological rationality: The recognition heuristic. Psychological Review, 109(1), 75-90.

http://dx.doi.org/10.1037/0033-295X.109.1.75

Goldstein, D. G., \& Gigerenzer, G. (2009). Fast and frugal forecasting. International Journal of Forecasting, 25(4), 760-772.

https://doi.org/10.1016/j.ijforecast.2009.05.010

Gorji, M. B., \& Rahimian, P. (2011). The study of barriers to entrepreneurship in men and women. Australian Journal of Business and Management Research, 1(9), 3136.

Granovetter, M. S. (1973). The strength of weak ties. American Journal of Sociology, 78(6), 1360-1380. https://doi.org/10.1016/B978-0-12-442450-0.50025-0

Granovetter, M. S. (1985). Economic action and social structure: The problem of embeddedness. American Journal of Sociology, 91(3), 481-510. https://doi.org/10.1086/228311

Griffin, D. W., \& Varey, C. A. (1996). Towards a consensus on overconfidence. Organizational Behavior and Human Decision Processes, 65(3), 227-231. http://dx.doi.org/10.1006/obhd.1996.0023

Gudmundsson, S. V., \& Lechner, C. (2013). Cognitive biases, organization, and entrepreneurial firm survival. European Management Journal, 31(3), 278-294. https://doi.org/10.1016/j.emj.2013.01.001

Gupta, V. K., Turban, D. B., Wasti, S. A., \& Sikdar, A. (2009). The role of gender stereotypes in perceptions of entrepreneurs and intentions to become an entrepreneur. Entrepreneurship Theory and Practice, 33(2), 397-417. 
https://doi.org/10.1111/j.1540-6520.2009.00296.x

Gurel, E., Altinay, L., \& Daniele, R. (2010). Tourism students' entrepreneurial intentions. Annals of Tourism Research, 37(3), 646-669.

https://doi.org/10.1016/j.annals.2009.12.003

Hair, J. F., Black, W. C., Babin, B. J., Anderson, R. E., \& Tatham, R. L. (2006). Multivariate data analysis. Upper Saddle River, Pearson Prentice Hall.

Hayward, M. L., Forster, W. R., Sarasvathy, S. D., \& Fredrickson, B. L. (2010). Beyond hubris: How highly confident entrepreneurs rebound to venture again. Journal of Business Venturing, 25(6), 569-578.

https://doi.org/10.1016/j.jbusvent.2009.03.002

Herz, H., Schunk, D., \& Zehnder, C. (2014). How do judgmental overconfidence and overoptimism shape innovative activity?. Games and Economic Behavior, 83, 123. https://doi.org/10.1016/j.geb.2013.11.001

Hmieleski, K. M., \& Baron R. A. (2009). Entrepreneurs' optimism and new venture performance: A social cognitive perspective. Academy Management Journal, 52(3), 473-488. https://doi.org/10.1016/j.geb.2013.11.001

Jacobsen, B., Lee, J. B., Marquering, W., \& Zhang, C.Y. (2014). Gender differences in optimism and asset allocation. Journal of Economic Behavior \& Organization, 107(PartB), 630-651. https://doi.org/10.1016/j.jebo.2014.03.007

Karimi, S., Biemans, H. J., Lans, T., Chizari, M., \& Mulder, M. (2016). The impact of entrepreneurship education: A study of Iranian students' entrepreneurial intentions and opportunity identification. Journal of Small Business Management, 54(1), 187-209. https://doi.org/10.1111/jsbm.12137

Kautonen, T., van Gelderen, M., \& Fink, M. (2015). Robustness of the theory of planned behavior in predicting entrepreneurial intentions and actions. Entrepreneurship Theory and Practice, 39(3), 655-674.

https://doi.org/10.1111/etap.12056

Kim, H. (2017). "Strength of weak Ties," Neighborhood ethnic heterogeneity, and depressive symptoms among adults: A multilevel analysis of Korean General Social Survey (KGSS) 2012. Social Sciences, 6(2), 65-81.

https://doi.org/10.3390/socsci6020065

Kim, S. M., \& Sherraden, M. (2014). The impact of gender and social networks on microenterprise business performance. Journal of Sociology \& Social Welfare, 41(3), 49-69.

Koellinger, P., Minniti, M., \& Schade, C. (2007). I think I can, I think I can: Overconfidence and entrepreneurial behavior. Journal of Economic Psychology, 28(4), 502-527. https://doi.org/10.1016/j.joep.2006.11.002

Koudstaal, M., Sloof, R., \& Van Praag, M. (2015). Are entrepreneurs more optimistic 
and overconfident than managers and employees?. Tinbergen Institute Discussion Paper.

Krueger, N. (1993). The impact of prior entrepreneurial exposure on perceptions of new venture feasibility and desirability. Entrepreneurship Theory and Practice, 18(1), 5-21. https://doi.org/10.1177/104225879301800101

Lee, M. K. Cheung, C. M., \& Chen, Z. (2007). Understanding user acceptance of multimedia messaging services: An empirical study. Journal of the Association for Information Science and Technology, 58(13), 2066-2077.

https://doi.org/10.1002/asi.20670

Lewis, K. V., Harris, C., Morrison, R., \& Ho, M. (2015). The entrepreneurshipmotherhood nexus. Career Development International, 20(1), 21-37. https://doi.org/10.1108/CDI-07-2014-0090

Liao, J., \& Welsch, H. (2005). Roles of social capital in venture creation: Key dimensions and research implications. Journal of Small Business Management, 43(4), 345-362. https://doi.org/10.1111/j.1540-627X.2005.00141.X

Liñán, F., \& Santos, F. J. (2007). Does social capital affect entrepreneurial intentions?. International Advances in Economic Research, 13(4), 443-453. https://doi.org/10.1007/s11294-007-9109-8

Liñán, F., Urbano, D., \& Guerrero, M. (2011). Regional variations in entrepreneurial cognitions: Start-up intentions of university students in Spain. Entrepreneurship and Regional Development, 23(3-4), 187-215.

https://doi.org/10.1080/08985620903233929

Lounsbury, J. W., Steel, R. P., Loveland, J. M., \& Gibson, L. W. (2004). An investigation of personality traits in relation to adolescent school absenteeism. Journal of Youth and Adolescence, 33(5), 457-466.

https://doi.org/10.1023/B:JOYO.0000037637.20329.97

Lowe, R. A., \& Ziedonis, A. A. (2006). Overoptimism and the performance of entrepreneurial firms. Management Science, 52(2), 173-186.

https://doi.org/10.1287/mnsc.1050.0482

Martin, C. L., Ruble, D. N., \& Szkrybalo, J. (2002). Cognitive theories of early gender development. Psychological Bulletin, 128(6), 903-933.

http://dx.doi.org/10.1037/0033-2909.128.6.903

Masters, R., \& Meier, R. (1988). Sex differences and risk-taking propensity of entrepreneurs. Journal of Small Business Management, 26(1), 31.

McEvily, B., Perrone, V., \& Zaheer, A. (2003). Trust as an organizing principle. Organization Science, 14(1), 91-103. https://doi.org/10.1287/orsc.14.1.91.12814

Minhas, W. A. (2018). Advancing entrepreneurship in the United Arab Emirates: Startup challenges and opportunities. Springer. 
Mitchell, R. K., Busenitz, L. W., Lant, T., McDougall, P. P., Morse, E. A., \& Smith, J. B. (2002). Toward a theory of entrepreneurial cognition: Rethinking the people side of entrepreneurship research. Entrepreneurship Theory and Practice, 27(2), 93-104. https://doi.org/10.1111/1540-8520.00001

Molyneux, M. (2002). Gender and the silences of social capital: Lessons from Latin America. Development and Change, 33(2), 167-188.

https://doi.org/10.1111/1467-7660.00246

Moore, D. A., \& Healy, P. J. (2008). The trouble with overconfidence. Psychological Review. 115(2), 502-577. http://dx.doi.org/10.1037/0033-295X.115.2.502

Moore, G. (1990). Structural determinants of men's and women's personal networks. American Sociological Review, 55(5), 726-735. https://doi.org/10.2307/2095868

Moscovici, S. (1984). The phenomenon of social representations. In R. Farr \& S. Mascovici (Eds.) Social representations (pp.3-70). Cambridge University Press.

Mueller, S. L., \& Dato-on, M. C. (2013). A cross cultural study of gender-role orientation and entrepreneurial self-efficacy. International Entrepreneurship and Management Journal, 9(1), 1-20. https://doi.org/10.1007/s11365-011-0187-y

Mulaik, S. A., James, L. R., Van Alstine, J., Bennett, N., Lind, S., \& Stilwell, C. D. (1989). Evaluation of goodness-of-fit indices for structural equation models. Psychological Bulletin, 105(3), 430-445.

http://dx.doi.org/10.1037/0033-2909.105.3.430

Munch, A., McPherson, J. M., \& Smith-Lovin, L. (1997). Gender, children, and social contact: The effects of childrearing for men and women. American Sociological Review, 62(4), 509-520. http://doi.org/10.2307/2657423

Murphy, J. P. (2011). A $2 * 2$ conceptual foundation for entrepreneurial discovery theory. Entrepreneurship Theory and Practice, 35(2), 359-374. https://doi.org/10.1111/j.1540-6520.2010.00368.x

Nahapiet, J., \& Ghoshal, S. (1998). Social capital, intellectual capital, and the organizational advantage. Academy of Management Review, 23(2), 242-266. https://doi.org/10.5465/amr.1998.533225

Niederle, M., \& Vesterlund, L. (2007). Do women shy away from competition? Do men compete too much?. The Quarterly Journal of Economics, 122(3), 1067-1101. https://doi.org/10.1162/qjec.122.3.1067

Nowiński, W., Haddoud, M. Y., Lančarič, D., Egerová, D., \& Czeglédi, C. (2019). The impact of entrepreneurship education, entrepreneurial self-efficacy and gender on entrepreneurial intentions of university students in the Visegrad countries. Studies in Higher Education, 44(2), 361-379.

https://doi.org/10.1080/03075079.2017.1365359

Nunnally, J. C. (1978). Psychometric theory. New York: McGraw-Hill. 
Palich, L. E., \& Bagby, D. (1995). Using cognitive theory to explain entrepreneurial risk-taking: Challenging conventional wisdom. Journal of Business Venturing, 10(6), 425-438. https://doi.org/10.1016/0883-9026(95)00082-J

Parker, S. C. (2006). Learning about the unknown: How fast do entrepreneurs adjust their beliefs?. Journal of Business Venturing, 21(1), 1-26.

https://doi.org/10.1016/j.jbusvent.2004.07.005

Parker, S. C. (2009). The economics of entrepreneurship. Cambridge: Cambridge University Press.

Pérez-López, M. C., González-López, M. J., \& Rodríguez-Ariza, L. (2016). Competencies for entrepreneurship as a career option in a challenging employment environment. Career Development International, 21(3), 214-229. https://doi.org/10.1108/CDI-07-2015-0102

Pérez-Macías, N., Fernández-Fernández, J. L., \& Rua Vieites, A. (2019). Entrepreneurial intentions: Trust and network ties in online and face-to-face students. Education+ Training, 61(4), 461-479.

https://doi.org/10.1108/CDI-07-2015-0102

Praag, C. M. V., \& Versloot, P. H. (2007). What is the value of entrepreneurship? : A review of recent research. Small Business Economics, 29(4), 351-382. https://doi.org/10.1007/s11187-007-9074-x

Putnam, R. D. (2000). Bowling alone: The collapse and revival of American community. New York: Simon and Schuster.

Read, S., Song, M., \& Smit, W. (2009). A meta-analytic review of effectuation and venture performance. Journal of Business Venturing, 24(6), 573-587. https://doi.org/10.1016/j.jbusvent.2008.02.005

Roberts, M. L., \& Wortzel, L. H. (1979). New life-style determinants of woman's food shopping behavior. Journal of Marketing, 43(3), 28-39.

https://doi.org/10.1177/002224297904300303

Robinson, S., \& Stubberud, H. A. (2011). Social networks and entrepreneurial growth. International Journal of Management and Information Systems, 15(4), 65-70. https://doi.org/10.19030/ijmis.v15i4.5802

Russo, J., \& Schoemaker, P. (1992). Managing overconfidence. Sloan Management Review, 33(2), 7-17.

Salancik, G., Pfeffer, J. (1978). A social information processing approach to job attitudes and task design. Administrative Science Quarterly, 23(2), 224-253. https://doi.org/10.2307/2392563

Schaefer, P., Williams, C., Goodie, A., \& Campbell, K. (2004). Overconfidence and the big five. Journal of Research in Personality, 38(5), 473-480. https://doi.org/10.1016/j.jrp.2003.09.010 
Scheier, M. F., Carver, C. S., \& Bridges, M. W. (1994). Distinguishing optimism from neuroticism (and trait anxiety, self-mastery, and self-esteem): A reevaluation of the life orientation test. Journal of Personality and Social Psychology, 67(6), 10631078. https://doi.org/10.1037//0022-3514.67.6.1063

Schlaegel, C., \& Koenig, M. (2014). Determinants of entrepreneurial intent: A metaanalytic test and integration of competing models. Entrepreneurship Theory and Practice, 38(2), 291-332. https://doi.org/10.1111/etap.12087

Schwenk, C. R. (1986). Information, cognitive biases, and commitment to a course of action. Academy of Management Review, 11(2), 298-310.

https://doi.org/10.2307/258461

Seibert, S. E., Kraimer, M. L., \& Liden, R. C. (2001). A social capital theory of career success. Academy of Management Journal, 44(2), 219-237.

https://doi.org/10.5465/3069452

Seligman, M. E. P., \& Schulman, P. (1986). Explanatory style as a predictor of productivity and quitting amongst life insurance sales agents. Journal of Personality and Social Psychology, 50(4), 832-838.

https://doi.org/10.1037//0022-3514.50.4.832

Shane, S., \& Venkataraman, S. (2000). The promise of entrepreneurship as a field of research. Academy Management Review, 25(1), 217-226.

https://doi.org/10.5465/amr.2000.2791611

Shepherd, D. A. (2015). Party on! A call for entrepreneurship research that is more interactive, activity based, cognitively hot, compassionate, and prosocial. Journal of Business Venturing, 30(4), 489-507.

https://doi.org/10.1016/j.jbusvent.2015.02.001

Shepherd, D. A., \& Krueger, N. F. (2002). An intentions-based model of entrepreneurial teams social cognition. Entrepreneurship Theory and Practice, 27(2), 167-185. https://doi.org/10.1111/1540-8520.00005

Shinnar, R. S., Hsu, D. K., Powell, B. C., \& Zhou, H. (2018). Entrepreneurial intentions and start-ups: Are women or men more likely to enact their intentions?. International Small Business Journal, 36(1), 60-80. https://doi.org/10.1177/0266242617704277

Singer, S., Amorós, J. E., \& Arreola, D. M. (2015). Global entrepreneurship monitor: 2011 global report. London Business School.

Sobel, M. E. (1982). Asymptotic confidence intervals for indirect effects in structural equation models. Sociological Methodology, 13, 290-312. https://doi/org/10.2307/270723

Tajfel, H., \& Turner, J. C. (1986). The social identity theory of intergroup behavior. In S. Worchel, \& W. G. Austin (Eds.) Psychology of intergroup relations (pp.7-24). 
Chicago, Nelson-Hall.

Tognazzo, A., Gubitta, P., \& Gianecchini, M. (2016). "My old and my new family"-

The impact of family relationships on students' entrepreneurial intentions: An Italian study. International Review of Entrepreneurship, 14(4), 447-468.

Trevelyan, R. (2008). Optimism, overconfidence and entrepreneurial activity. Management Decision, 46(7), 986-1001.

https://doi.org/10.1108/00251740810890177

Weinstein, N. D. (1982). Unrealistic optimism about susceptibility to health problems. Journal of Behavioral Medicine, 5(4), 441-460.

https://doi.org/10.1007/BF00845372

Weinstein, N. D. (1987). Unrealistic optimism about susceptibility to health problems:

Conclusions from a community-wide sample. Journal of Behavioral Medicine, 10(5), 481-500. https://doi.org/10.1007/BF00846146

Williams, D. (2006). On and off the 'net: Scales for social capital in an online era.

Journal of Computer-Mediated Communication, 11(2), 593-628. https://doi.org/10.1111/j.1083-6101.2006.00029.x

Wilson, F., Kickul, J., \& Marlino, D. (2007). Gender, entrepreneurial self-efficacy, and entrepreneurial career intentions: Implications for entrepreneurship research. Entrepreneurship Theory and Practice, 31(1), 387-406.

https://doi.org/10.1111/j.1540-6520.2007.00179.x

Zacharakis, A. L., \& Shepherd, D. A. (2001). The nature of information and overconfidence on venture capitalists' decision making. Journal of Business Venturing, 16(4), 311-332. https://doi.org/10.1016/S0883-9026(99)00052-X

Zampetakis, L. A., Bakatsaki, M., Litos, C., Kafetsios, K. G., \& Moustakis, V. (2017). Gender-based differential item functioning in the application of the theory of planned behavior for the study of entrepreneurial intentions. Frontiers in Psychology. 8, Article 451. https://doi.org/10.3389/fpsyg.2017.00451

Dr. Lin-Ju Cheng is an assistant professor of the Department of Marketing and Logistics Management, St. John's University. Her current research interests include innovation and entrepreneurship, strategy management, and business management.

Dr. Chun-Chieh Liao (Corresponding author) is an assistant professor of the Department of International Trade, Chinese Culture University. His current research interests include business management, financial management, and innovation and entrepreneurship management. 